\title{
ASSESSMENT OF BANK EROSION, ACCRETION AND CHANNEL SHIFTING USING REMOTE SENSING AND GIS: CASE STUDY - LOWER COURSE OF THE BOSNA RIVER
}

\author{
Novica LOVRIC, RADISLAV TOSIC \\ Faculty of Sciences, University of Banja Luka, Bosnia and Herzegovina \\ Manuscript received: November 30, 2015 \\ Revised version: March 8, 2016
}

\begin{abstract}
Lovric N., Tosic R., 2016. Assessment of bank erosion, accretion and lateral channel migration using remote sensing and GIS: Case study - Lower part of the Bosna River. Quaestiones Geographicae 35(1), Bogucki Wydawnictwo Naukowe, Poznań, pp. 81-92, 4 figs, 4 tables.

ABSTRACT: River bank erosion, accretion and lateral channel migration are the most important geomorphological processes, which attract a great deal of attention from river engineering scientist over the last century. In the presented study, we assessed how the river's shape and position have changed during 1958-2013 period using remote sensing and GIS. We have identified that the total area of bank erosion during given period equalled $8.3430 \mathrm{~km}^{2}$, of which $3.2593 \mathrm{~km}^{2}$ were on the left bank and $5.0837 \mathrm{~km}^{2}$ on the right bank. The total area of bank accretion from 1958 to 2013 equalled $10.7074 \mathrm{~km}^{2}$, of which $5.4115 \mathrm{~km}^{2}$ was on the left bank and $5.2958 \mathrm{~km}^{2}$ on the right bank. The Bosna riverbed average movement in the period 1958-2013 was established in the amount of $132.4 \mathrm{~m}$. During this period, the average lateral channel migration was $2.5 \mathrm{~m}$ per year. The data presented here are significant for practical issues such as predicting channel migration rates for engineering and planning purposes, soil and water management.
\end{abstract}

KEY WORDS: bank erosion, channel migration, GIS, remote sensing, Bosna River

Corresponding author: Novica Lovric (novical@blic.net)

\section{Introduction}

Understanding the mechanisms and rates of bank erosion, accretion and lateral channel migration has fundamental significance, as well as results of these researches which are applicable in the field of water and soil resources management, hydro-technical works, and in different aspects of the environmental protection (Thorne 1982, Lawler 1993). Scientific and engineering interest for bank erosion, accretion and lateral channel migration in the Bosnia and Herzegovina has been increased for three main reasons. Firstly, bank erosion plays an important role in control of channel stability. Secondly, bank erosion have significant contribution to the sediment load, and thirdly, destruction of flood plain land, land loss and land use changes is associated with serious bank erosion. Also, lateral migration of the Bosna River has caused a serious problem because of disappearance of arable land and land use changes (Hooke 2003, Dragicevic et al. 2013, Tosic et al. 2014).

In the region, the consequences of changes in river course and bank erosion intensity have been well-documented in the literature (Thorne 1982, Lawler et al. 1999, Richard et al. 2005, Tiegs, Pohl 2005, Hooke 2007, Kiss et al. 2008, Nicoll, 
Hickin 2010, Radoane et al. 2010, Blanka, Kiss 2011, Yao et al. 2011, Zaharia et al. 2011, Floriou 2011, Roksandic et al. 2011, Henshaw et al. 2013, Dragicevic et al. 2012, 2013, Tosic et al. 2014).

The Bosna River is a boundary watercourse along the administrative border between the Republic of Srpska and the Federation of Bosnia and Herzegovina and this valley is very important because it traced the future Corridor $5 c$ (Budapest-Osijek-Doboj-Sarajevo-Ploce) and Trans-Dinarides geostrategic directrix between the Pannonian and the Adriatic Basin (Dragicevic et al. 2013). The Bosna River provides a good opportunity to study bank erosion, accretion and lateral channel migration, considering all the problems that burdened the lower course of the Bosna River we started analysing these processes using available data and GIS. The availability of aerial photography, orthophoto images, and GIS has opened up to possibility to research bank erosion, accretion and lateral channel migration. Worldwide, several different techniques have been used to quantify these processes and different time span, 1 to 10 years for field measurements and 10 to 200 years for maps and aerial photographs (Hooke 1979, 1980, 2003, Hooke, Redmond 1989, Duan 2005).

The objectives of this study were to assess the rate of bank erosion and accretion, as well as rate of lateral channel migration of Bosna River using remote sensing and GIS. The data presented here represent a base in understanding the dynamics of bank erosion, accretion and lateral channel migration of Bosna River; they are also significant to practical issues such as predicting channel migration rates for engineering and planning purposes.

\section{Study area}

The research covered the southern part of the Pannonian Basin in the Bosnia and Herzegovina (Fig. 1). The study area is located along the lower course of the Bosna River, with total channel length of $27.645 \mathrm{~km}$. The Bosna River drains the central part of the Dinaric Karst Massif and the central part of Bosnia and Herzegovina. The drainage basin area is of $10,662 \mathrm{~km}^{2}$, course length of $275 \mathrm{~km}$, mean annual discharge at the confluence with the Sava River is $180.5 \mathrm{~m}^{3} \mathrm{~s}^{-1}$, specific discharge $15.6 \mathrm{ls}^{-1} \mathrm{~km}^{-2}$, and the average fall is $1.48 \mathrm{~m} \mathrm{~km}^{-1}$ (Dragicevic et al. 2013).

The tectonic characteristics of this area, more precisely, the Posavski Fault, have influenced the orientation of the hydrological network in the Bosna River basin. The decrease in the stream velocity in the lower course of the Bosna River is caused by the tectonic movements of sinking in the northern part of the basin. This process resulted sediment accumulation in the riverbeds, bank erosion, formation of meanders, and changes in the river course. Thus, the study area is characterised by intense lateral dynamics of the river channels. Morphology of study area is characterised by almost horizontal terrain with dominant riverbed of Bosna River and its terraces. Excessive type of deep and lateral erosion is present in the riverbed. The river often meander and cut into its own alluvium which causes sedimentary facies of the riverbed to be in constant movement. Total thickness of Quaternary fluvial sediments is estimated up to $150-200 \mathrm{~m}$ which indicates huge effect of erosion and accumulation processes.

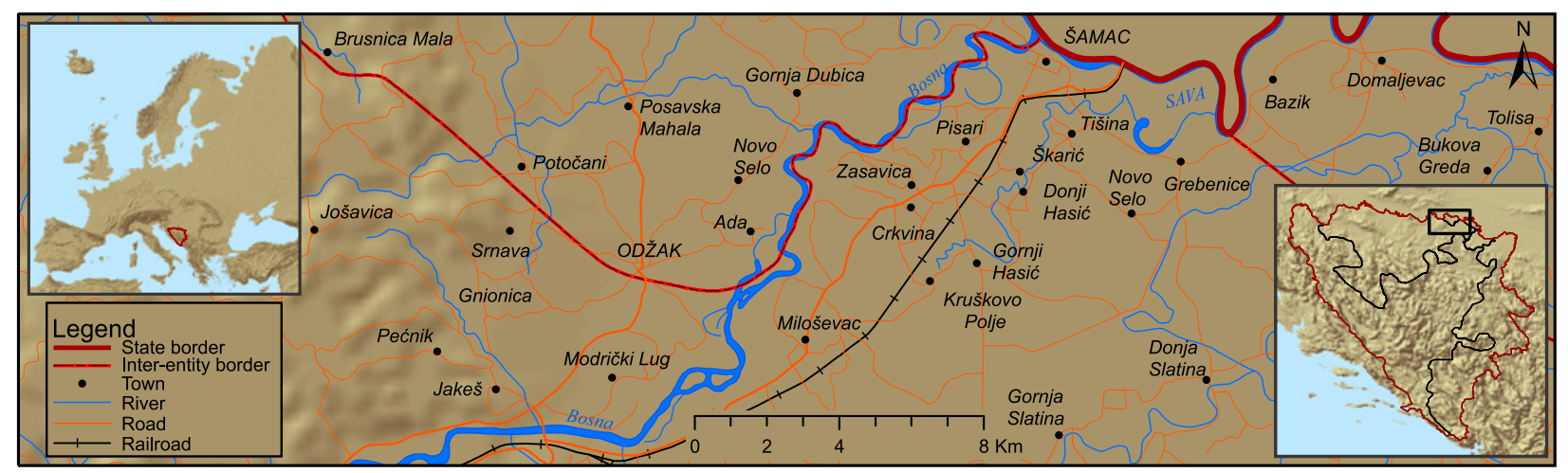

Fig. 1. Location of the study area - lower reach of the Bosna River. 
According to Basic Geological Map data, layers for Doboj and Slavonski Brod, three levels of river material accumulation have been detected (Tosic et al. 2014). First level is third lake-river terrace $\left(t_{3}\right)$ isolated as a relatively narrow zone in western part of study area between plioquaternery deposits on the west and sediments of second terrace on the east. It is represented by clay, sand and gravel material, which indicates its proluvial origin. Second level, represented by sediments of second river terrace $\left(t_{2}\right)$ is detected on altitudes between 100 and $112 \mathrm{~m}$. It is created by shift of the channel of Bosnia River towards east. Lithological composition contain clay, sandclay and large gravel and sand beneath. Third level, first river terrace $\left(t_{1}\right)$, has accumulation character with typical composition made from gravel and medium and large grain boulder, unevenly sorted, with less participation of silt and clay. These fractions alternate both laterally and vertically which indicate changeable regime of deposition and dynamics of Bosna River flow. It is marked by occasional section built by sub-recent meanders of Bosna River, approximately 25 $\mathrm{km}$ in length, from town of Modrica to Bosna and Sava River confluence. Total thickness of first, second and third river terrace is $100-150 \mathrm{~m}$, determined by drilling. Organogenic-marsh sediments are found on both banks of Bosna River. They originated by slow descend of this area, and partly by waterlogging due to periodical rising of groundwater level. Deposition of marshes is composed by dark green and dark grey clay, clay-alevrit sediments, small grained sand and gravel, moss, etc. Flood sediments could be found on both banks of study area. These Quaternary formations originated during flood periods. Lithologically, these formations are dominantly made from sand, silt and clay-alevrit sediments, often waterlogged. Alluvial deposition is formed in vicinity of riverbed of Bosna River and wider stream valleys. Bosna River changed its flow very often, depositing in and nearby its riverbed huge amounts of boulder and sand materials. Flowing through its own deposition, the river often meander and overflowing. Analysis of deposit in riverbed and gravel pits showed that lowest part of the column is made from large grained sand and gravel almost unsorted with poorly visible stratification. These deposits in the riverbed are frequently transported and renewed again, forming unstable and relatively stable terrain. Estimated thickness of these deposits is $10 \mathrm{~m}$ (Tosic et al. 2014).

\section{Methods}

All analyses completed for this study are based on the location and magnitude of recent historic changes to the planform geometry of the Bosna River. Landscape studies using aerial photographs, satellite images and different scale paper maps are useful to determine the river course changes. There is a large amount of literature indicating the usefulness of identifying planform changes in channel geometry using aerial photography and orthophoto in a geographic information system (GIS) environment (Petts 1989, Downward et al. 1994, Gurnell et al. 1994, Downward 1995, Gurnell 1997, Winterbottom, Gilvear 2000, Weng 2002, Wellmeyer et al. 2005, Grove et al. 2013). One of the main characteristics of remote sensing is its capability of generating a large amount of information, frequently and spatially and thus studying river morphology. A review of techniques used to measure river bank retreat rates is provided by Lawler (1993).

Comparing the data from different periods, we defined the evolution of the river channel position over different time series. In this study, we developed a time series of georeferenced data using a combination of aerial photography from 1958, 1976 and orthophoto images from 2001, 2006, 2008 and 2013. Aerial photogrammetry surveying of the lower part of the Bosna River was implemented by Z/I DMC camera with 120 $\mathrm{mm}$ focus and image dimension of $1,324 \times 7,680$ pixels. Scale of this survey was 1:33,333 and as a result the spatial image resolution was $40 \mathrm{~m}$. Reconnaissance of known trigonometric marks and GPS detection of new orientation marks along the whole recorded area of the lower part of the Bosna River made aero-triangulation and block alignment plausible. When aero-triangulation was finished the photogrammetric image processing, digital terrain model development, orthorectification and cartographic processing took place. Orthorectification of aerial images and conversion from central to orthogonal projection (Gauss-Krüger projection (VI zone) World Geodetic System 1984) was implemented 
based on previously developed digital terrain model and stereopairs of aerial photographs. The sheets of digital orthophoto plan in scale 1:5,000 and resolution $50 \mathrm{~cm}$ were developed using orthorectification process. Orthophoto plans were created in TIFF+tfw format for simplified use in ArcGIS software, while aerial photographs were processed in PHOTOMOD software package.

In the ArcGIS software, we created a continuous polygon to represent the river channel in each year using the image data. We determined the changes in the locations of both riverbanks during five periods: 1958 to 1976; 1976 to 2001; 2001 to 2006; 2006 to 2008; 2008 to 2013. The results revealed the places where erosion and accretion occurred during each period. We calculated erosion and accretion separately for each side of the river. We digitized the shorelines at the start of each period, copied the left shorelines of 1958 and 2013 into a single layer, and processed them using the GIS software to create polygons that represented the difference between the two positions of river shoreline. If a polygon was positioned to the left of the 1958 shoreline, it represented an erosion polygon; if a polygon was positioned to the right of the 1958 shoreline, it represented an accretion polygon. We used the same process to assess erosion and accretion of the right bank, but with the following change: polygons to the left and right of the 1958 shoreline represented accretion and erosion, respectively. Summing the areas of these polygons provided the total eroded and accreted areas from 1958 to 2013. After determining these areas, we added the 1976, 2001, 2006, 2008 and 2013 shorelines sequentially to subdivide each of the polygons into smaller polygons that represented the shorelines on each of these dates. We used the Esri ${ }^{\circledR}$ ArcMap ${ }^{\mathrm{TM}} 10.1$ (ArcGIS 10.1 for Desktop) software to calculate the areas of overlap between the shoreline in each year and the boundaries of the polygon that contained that portion of the shoreline. We then used the same approach that we used for the period from 1958 to 2013 to calculate the erosion and accretion between consecutive years (Downward et al. 1994, Yao et al. 2011).

Comparing the data from different periods, we determined the rate of lateral channel migration over different periods. The position of the channel centreline was marked in each data source (1958, 1976, 2001, 2006, 2008 and 2013). River shorelines were digitized using the water boundary because it is clearly defined in the aerial photography and orthophto images. Furthermore, the two digitized shorelines are used in ArcGIS to generate a centreline of active channel, and then the channel migration rate was calculated (Hooke 1979, 1980, Hudson, Kesel 2000, Winterbottom, Gilevar 2000, Mount, Louis 2005, Hughes et al. 2006).

\section{Results}

In our analysis, we identified that the total area of bank erosion from 1958 to 2013 equalled $8.3430 \mathrm{~km}^{2}$, of which $3.2593 \mathrm{~km}^{2}$ were on the left bank and $5.0837 \mathrm{~km}^{2}$ on the right bank. The total area of bank accretion from 1958 to 2013 equalled $10.7074 \mathrm{~km}^{2}$, of which $5.4115 \mathrm{~km}^{2}$ were on the left bank and $5.2958 \mathrm{~km}^{2}$ on the right bank (Table 1).

These totals translate into annual bank erosion rates of $0.1360,0.1210,0.2366,0.2977$ and $0.2182 \mathrm{~km}^{2}$ shows increase from 1958 to 2008 . The annual rates that accreted along the study reaches were from $0.2565,0.1363,0.0623,0.8659$ and $0.1281 \mathrm{~km}^{2}$ (Fig. 2). Our analysis identified 227 erosion plots on the left bank and 202 erosion plots on the right bank (Table 2).

Table 1. Area of riverbank erosion and accretion of the Bosna River from 1958 to 2013.

\begin{tabular}{|c|c|c|c|c|c|c|}
\hline \multirow{2}{*}{ Time span } & \multicolumn{3}{|c|}{ Area of erosion $\left(\mathrm{km}^{2}\right)$} & \multicolumn{3}{c|}{ Area of accretion $\left(\mathrm{km}^{2}\right)$} \\
\cline { 2 - 7 } & Left bank & Right bank & Total & Left bank & Right bank & Total \\
\hline $1958-1976$ & 1.2186 & 1.2293 & 2.4479 & 1.7747 & 2.8417 & 4.6165 \\
\hline $1976-2001$ & 0.8229 & 2.2027 & 3.0256 & 2.3503 & 1.0565 & 3.4068 \\
\hline $2001-2006$ & 0.4838 & 0.6991 & 1.1829 & 0.2233 & 0.0884 & 0.3117 \\
\hline $2006-2008$ & 0.3765 & 0.2188 & 0.5954 & 0.5451 & 1.1866 & 1.7317 \\
\hline $2008-2013$ & 0.3575 & 0.7337 & 1.0912 & 0.5180 & 0.1227 & 0.6407 \\
\hline Total (1958-2013) & 3.2593 & 5.0837 & 8.3430 & 5.4115 & 5.2958 & 10.7074 \\
\hline
\end{tabular}


On the left bank, only 1 erosion plot was larger than $0.5 \mathrm{~km}^{2}$, with total area of $0.6825 \mathrm{~km}^{2}$ (20.94\% of total area), while 2 erosion plots on right bank are larger than $0.5 \mathrm{~km}^{2}$, with total area of $1.0625 \mathrm{~km}^{2}(20.90 \%$ of total area). In contrast, 226 plots on left bank were smaller than $0.5 \mathrm{~km}^{2}$, and these totalled $2.5768 \mathrm{~km}^{2}$. On right bank, 200 plots were smaller than $0.5 \mathrm{~km}^{2}$, and these totalled $4.0212 \mathrm{~km}^{2}$.

Our analysis identified 227 accretion plots on the left bank and 207 accretion plots on the right bank (Table 3). On the left bank, no accretion plot larger than $0.5 \mathrm{~km}^{2}$, while 3 accretion plots on right bank are larger than $0.5 \mathrm{~km}^{2}$, with total area of $2.5778 \mathrm{~km}^{2}$ (48.67\% of total area). In contrast, 227 accretion plots on left bank were smaller than $0.5 \mathrm{~km}^{2}$, and these totalled $5.4115 \mathrm{~km}^{2}$. On right bank, 204 accretion plots were smaller than 0.5 $\mathrm{km}^{2}$, and these totalled $2.7180 \mathrm{~km}^{2}$.

The maximum of eroded areas $\left(0.6825 \mathrm{~km}^{2}\right)$ during the observed periods was on the left bank, from 1958 to 1976, while average area of erosion of both banks was $0.0499 \mathrm{~km}^{2}$ (Fig. 3). In this peri$\mathrm{od}$, the average area of the accretion along the left and right bank was $0.0942 \mathrm{~km}^{2}$. The average area of the erosion along the left and right bank from 1976 to 2001 was $0.0796 \mathrm{~km}^{2}$. Along both banks, in the same period, the average area of the accretion was $0.0920 \mathrm{~km}^{2}$. Along the left and right bank from 2001 to 2006, the average area of the erosion was $0.0079 \mathrm{~km}^{2}$. In the same period, along the left and right bank the average area of the accretion was $0.0020 \mathrm{~km}^{2}$. If we look at erosion of the left and right bank, the lowest average value in the

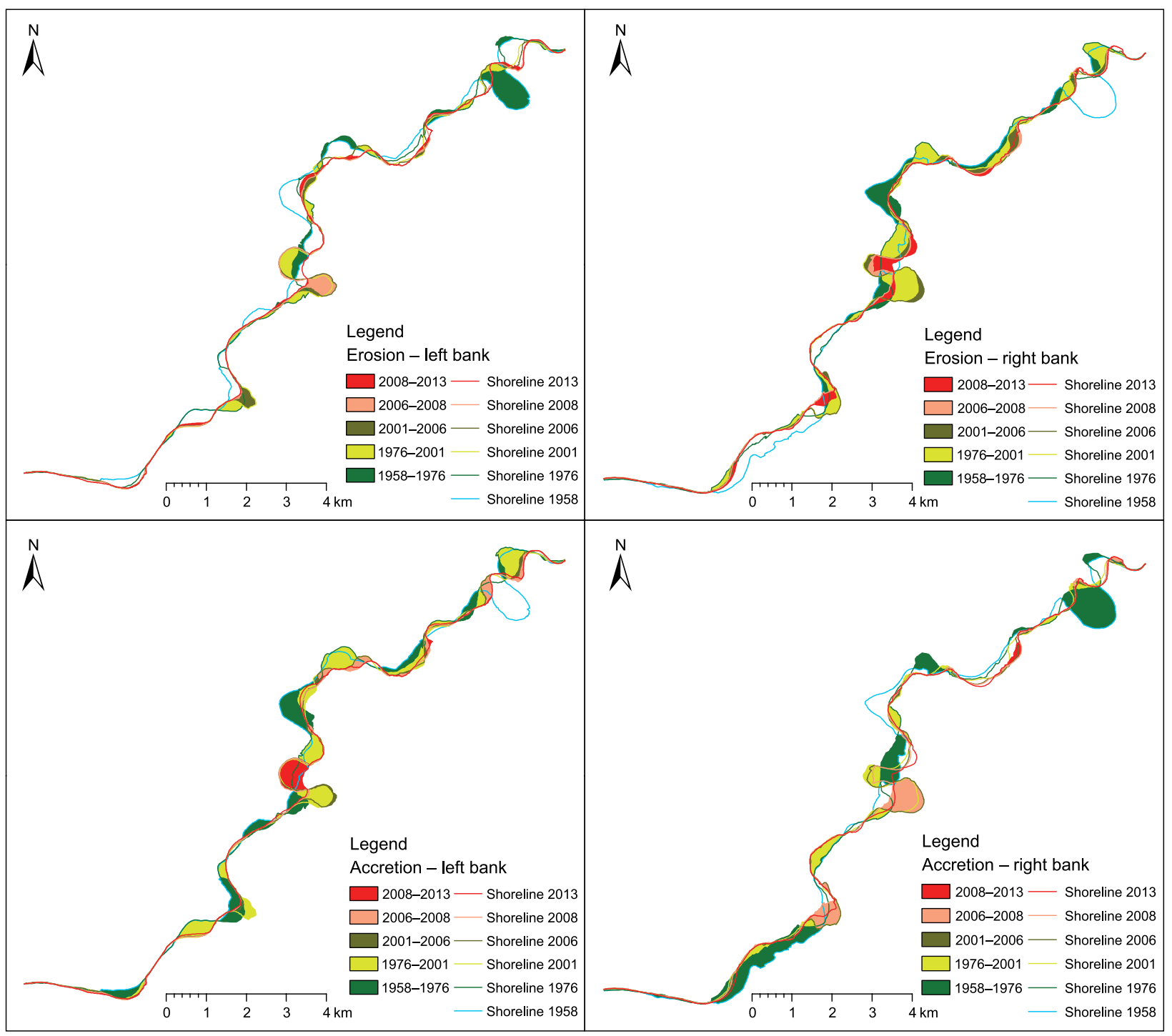

Fig. 2. Bank erosion and accretion during five periods from 1958 to 2013. 
Table 2. Distribution of the bank erosion area along the study reaches from 1958 to 2013.

\begin{tabular}{|c|c|c|c|c|c|c|c|c|c|c|c|c|}
\hline \multirow{3}{*}{ Time span } & \multicolumn{12}{|c|}{ Area of erosion $\left(\mathrm{km}^{2}\right)$} \\
\hline & \multicolumn{6}{|c|}{ Left river bank } & \multicolumn{6}{|c|}{ Right river bank } \\
\hline & $\begin{array}{c}0.001- \\
0.01\end{array}$ & $\begin{array}{c}0.01- \\
0.05\end{array}$ & $\begin{array}{c}0.05- \\
0.1\end{array}$ & $\begin{array}{c}0.1- \\
0.5\end{array}$ & $\begin{array}{c}0.5- \\
1\end{array}$ & Total & $\begin{array}{c}0.001- \\
0.01\end{array}$ & $\begin{array}{c}0.01- \\
0.05\end{array}$ & $\begin{array}{c}0.05- \\
0.1\end{array}$ & $\begin{array}{c}0.1- \\
0.5\end{array}$ & $\begin{array}{c}0.5- \\
1\end{array}$ & Total \\
\hline \multicolumn{13}{|c|}{ 1958-1976 } \\
\hline $\begin{array}{l}\text { Number } \\
\text { of plots }\end{array}$ & 21 & 3 & 2 & 2 & 1 & 29 & 13 & 1 & 2 & 3 & 1 & 20 \\
\hline $\begin{array}{l}\text { Total area } \\
\left(\mathrm{km}^{2}\right)\end{array}$ & 0.0297 & 0.0668 & 0.1347 & 0.3049 & 0.6825 & 1.2186 & 0.0128 & 0.0173 & 0.1549 & 0.5023 & 0.5420 & 1.2293 \\
\hline $\begin{array}{l}\text { Proportion } \\
\text { of total }(\%)\end{array}$ & 2.4382 & 5.4841 & 11.0532 & 25.0181 & 56.0065 & 100 & 1.0400 & 1.4067 & 12.5965 & 40.8637 & 44.0931 & 100 \\
\hline \multicolumn{13}{|c|}{ 1976-2001 } \\
\hline $\begin{array}{l}\text { Number } \\
\text { of plots }\end{array}$ & 10 & 5 & 5 & 2 & 0 & 22 & 4 & 3 & 2 & 6 & 1 & 16 \\
\hline $\begin{array}{l}\text { Total area } \\
\left(\mathrm{km}^{2}\right)\end{array}$ & 0.0229 & 0.1244 & 0.3442 & 0.3313 & 0.0000 & 0.8229 & 0.0032 & 0.1187 & 0.1485 & 1.4118 & 0.5205 & 2.2027 \\
\hline $\begin{array}{l}\text { Proportion } \\
\text { of total }(\%)\end{array}$ & 2.7836 & 15.1179 & 41.8341 & 40.2644 & 0.0000 & 100 & 0.1449 & 5.3894 & 6.7430 & 64.0944 & 23.6283 & 100 \\
\hline \multicolumn{13}{|c|}{ 2001-2006 } \\
\hline $\begin{array}{l}\text { Number } \\
\text { of plots }\end{array}$ & 66 & 9 & 1 & 1 & 0 & 77 & 58 & 9 & 3 & 2 & 0 & 72 \\
\hline $\begin{array}{l}\text { Total area } \\
\left(\mathrm{km}^{2}\right)\end{array}$ & 0.0269 & 0.2406 & 0.0738 & 0.1425 & 0.0000 & 0.4838 & 0.0208 & 0.2835 & 0.1694 & 0.2254 & 0.0000 & 0.6991 \\
\hline $\begin{array}{l}\text { Proportion } \\
\text { of total }(\%)\end{array}$ & 5.5655 & 49.7282 & 15.2461 & 29.4601 & 0.0000 & 100 & 2.9742 & 40.5535 & 24.2296 & 32.2428 & 0.0000 & 100 \\
\hline \multicolumn{13}{|c|}{ 2006-2008 } \\
\hline $\begin{array}{l}\text { Number } \\
\text { of plots }\end{array}$ & 36 & 4 & 0 & 1 & 0 & 41 & 43 & 5 & 1 & 0 & 0 & 49 \\
\hline $\begin{array}{l}\text { Total area } \\
\left(\mathrm{km}^{2}\right)\end{array}$ & 0.0241 & 0.0660 & 0.0000 & 0.2863 & 0.0000 & 0.3765 & 0.0286 & 0.0951 & 0.0951 & 0.0000 & 0.0000 & 0.2188 \\
\hline $\begin{array}{l}\text { Proportion } \\
\text { of total }(\%)\end{array}$ & 6.4125 & 17.5406 & 0.0000 & 76.0469 & 0.0000 & 100 & 13.0811 & 43.4690 & 43.4499 & 0.0000 & 0.0000 & 100 \\
\hline \multicolumn{13}{|c|}{$2008-2013$} \\
\hline $\begin{array}{l}\text { Number } \\
\text { of plots }\end{array}$ & 49 & 8 & 1 & 0 & 0 & 58 & 35 & 6 & 1 & 3 & 0 & 45 \\
\hline $\begin{array}{l}\text { Total area } \\
\left(\mathrm{km}^{2}\right)\end{array}$ & 0.0623 & 0.2300 & 0.0652 & 0.0000 & 0.0000 & 0.3575 & 0.0418 & 0.1084 & 0.0629 & 0.5206 & 0.0000 & 0.7337 \\
\hline $\begin{array}{l}\text { Proportion } \\
\text { of total (\%) }\end{array}$ & 17.4276 & 64.3426 & 18.2298 & 0.0000 & 0.0000 & 100 & 5.6950 & 14.7801 & 8.5777 & 70.9472 & 0.0000 & 100 \\
\hline
\end{tabular}


Table 3. Distribution of the bank accretion area along the study reaches from 1958 to 2013.

\begin{tabular}{|c|c|c|c|c|c|c|c|c|c|c|c|c|}
\hline \multirow{3}{*}{ Time span } & \multicolumn{12}{|c|}{ Area of accretion $\left(\mathrm{km}^{2}\right)$} \\
\hline & \multicolumn{6}{|c|}{ Left river bank } & \multicolumn{6}{|c|}{ Right river bank } \\
\hline & $\begin{array}{c}0.001- \\
0.01\end{array}$ & $\begin{array}{c}0.01- \\
0.05\end{array}$ & $\begin{array}{c}0.05- \\
0.1\end{array}$ & $\begin{array}{c}0.1- \\
0.5\end{array}$ & $\begin{array}{c}0.5- \\
1\end{array}$ & Total & $\begin{array}{c}0.001- \\
0.01\end{array}$ & $\begin{array}{c}0.01- \\
0.05\end{array}$ & $\begin{array}{c}0.05- \\
0.1\end{array}$ & $\begin{array}{c}0.1- \\
0.5\end{array}$ & $\begin{array}{c}0.5- \\
1\end{array}$ & Total \\
\hline \multicolumn{13}{|c|}{ 1958-1976 } \\
\hline $\begin{array}{l}\text { Number } \\
\text { of plots }\end{array}$ & 18 & 2 & 1 & 7 & 0 & 28 & 13 & 3 & 1 & 2 & 2 & 21 \\
\hline $\begin{array}{l}\text { Total area } \\
\left(\mathrm{km}^{2}\right)\end{array}$ & 0.0183 & 0.0593 & 0.0509 & 1.6463 & 0.0000 & 1.7747 & 0.0121 & 0.0891 & 0.0755 & 0.7001 & 1.9649 & 2.8417 \\
\hline $\begin{array}{l}\text { Proportion } \\
\text { of total }(\%)\end{array}$ & 1.0289 & 3.3419 & 2.8680 & 92.7612 & 0.0000 & 100 & 0.4260 & 3.1365 & 2.6572 & 24.6371 & 69.1432 & 100 \\
\hline \multicolumn{13}{|c|}{ 1976-2001 } \\
\hline $\begin{array}{l}\text { Number } \\
\text { of plots }\end{array}$ & 7 & 2 & 4 & 8 & 0 & 21 & 4 & 5 & 2 & 5 & 0 & 16 \\
\hline $\begin{array}{l}\text { Total area } \\
\left(\mathrm{km}^{2}\right)\end{array}$ & 0.0118 & 0.0312 & 0.3046 & 2.0027 & 0.0000 & 2.3503 & 0.0027 & 0.1369 & 0.1414 & 0.7755 & 0.0000 & 1.0565 \\
\hline $\begin{array}{l}\text { Proportion } \\
\text { of total }(\%)\end{array}$ & 0.5020 & 1.3289 & 12.9586 & 85.2105 & 0.0000 & 100 & 0.2563 & 12.9560 & 13.3834 & 73.4043 & 0.0000 & 100 \\
\hline \multicolumn{13}{|c|}{ 2001-2006 } \\
\hline $\begin{array}{l}\text { Number } \\
\text { of plots }\end{array}$ & 75 & 4 & 1 & 0 & 0 & 80 & 70 & 3 & 0 & 0 & 0 & 73 \\
\hline $\begin{array}{l}\text { Total area } \\
\left(\mathrm{km}^{2}\right)\end{array}$ & 0.0534 & 0.1101 & 0.0599 & 0.0000 & 0.0000 & 0.2233 & 0.0392 & 0.0492 & 0.0000 & 0.0000 & 0.0000 & 0.0884 \\
\hline $\begin{array}{l}\text { Proportion } \\
\text { of total }(\%)\end{array}$ & 23.8898 & 49.2987 & 26.8115 & 0.0000 & 0.0000 & 100 & 44.3282 & 55.6718 & 0.0000 & 0.0000 & 0.0000 & 100 \\
\hline \multicolumn{13}{|c|}{$2006-2008$} \\
\hline $\begin{array}{l}\text { Number } \\
\text { of plots }\end{array}$ & 40 & 5 & 2 & 2 & 0 & 49 & 50 & 6 & 0 & 1 & 1 & 58 \\
\hline $\begin{array}{l}\text { Total area } \\
\left(\mathrm{km}^{2}\right)\end{array}$ & 0.0326 & 0.1547 & 0.1341 & 0.2237 & 0.0000 & 0.5451 & 0.0574 & 0.1454 & 0.0000 & 0.3708 & 0.6130 & 1.1866 \\
\hline $\begin{array}{l}\text { Proportion } \\
\text { of total (\%) }\end{array}$ & 5.9733 & 28.3858 & 24.5950 & 41.0459 & 0.0000 & 100 & 4.8352 & 12.2556 & 0.0000 & 31.2524 & 51.6568 & 100 \\
\hline \multicolumn{13}{|c|}{$2008-2013$} \\
\hline $\begin{array}{l}\text { Number } \\
\text { of plots }\end{array}$ & 46 & 2 & 0 & 1 & 0 & 49 & 38 & 0 & 1 & 0 & 0 & 39 \\
\hline $\begin{array}{l}\text { Total area } \\
\left(\mathrm{km}^{2}\right)\end{array}$ & 0.0456 & 0.0252 & 0.0000 & 0.4472 & 0.0000 & 0.5180 & 0.0436 & 0.0000 & 0.0791 & 0.0000 & 0.0000 & 0.1227 \\
\hline $\begin{array}{l}\text { Proportion } \\
\text { of total (\%) }\end{array}$ & 8.7965 & 4.8701 & 0.0000 & 86.3334 & 0.0000 & 100 & 35.5435 & 0.0000 & 64.4565 & 0.0000 & 0.0000 & 100 \\
\hline
\end{tabular}



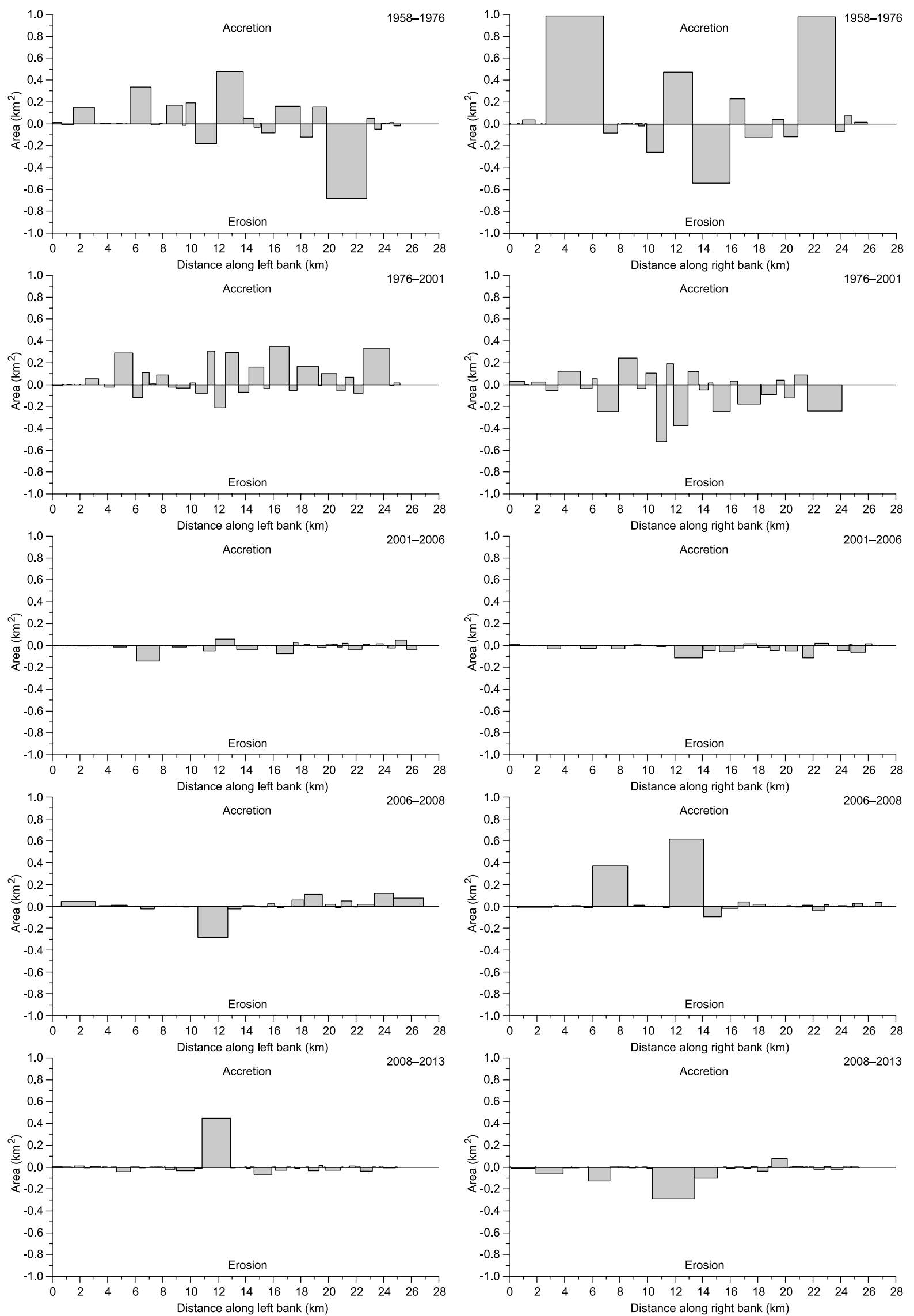

Fig. 3. Spatial distribution of erosion and accretion along the study reaches from 1958 to 2013. 
analysed periods was $0.0066 \mathrm{~km}^{2}(2006-2008)$. The maximum value $\left(0.2863 \mathrm{~km}^{2}\right)$ was on the left bank. During this period, along the left and right bank the average area of the accretion was 0.0161 $\mathrm{km}^{2}$. From 2008 to 2013, on both banks, the average area of erosion was $0.0105 \mathrm{~km}^{2}$. The average area of accretion on both banks was $0.0072 \mathrm{~km}^{2}$.

In the research sector (Fig. 4), the Bosna River length was $25.774 \mathrm{~km}$ in 1958 (sinuosity was 1.500), $24.869 \mathrm{~km}$ in 1976 (sinuosity was 1.448), $27.584 \mathrm{~km}$ in 2001 (sinuosity was 1.606), 27.073 $\mathrm{km}$ in 2006 (sinuosity was 1.576), 24.642 in 2008 (sinuosity was 1.435) and $23.949 \mathrm{~km}$ in 2013 (sinuosity was 1.394).

Analysis of the aerial photography and orthophoto images of the research area showed that the Bosna average channel shifting in the period 1958-2013 was established in the amount of 132.4 $\mathrm{m}$. Apart from this period, the maximum values of the period 1958-1976, 517.8 m, 1958-2001,

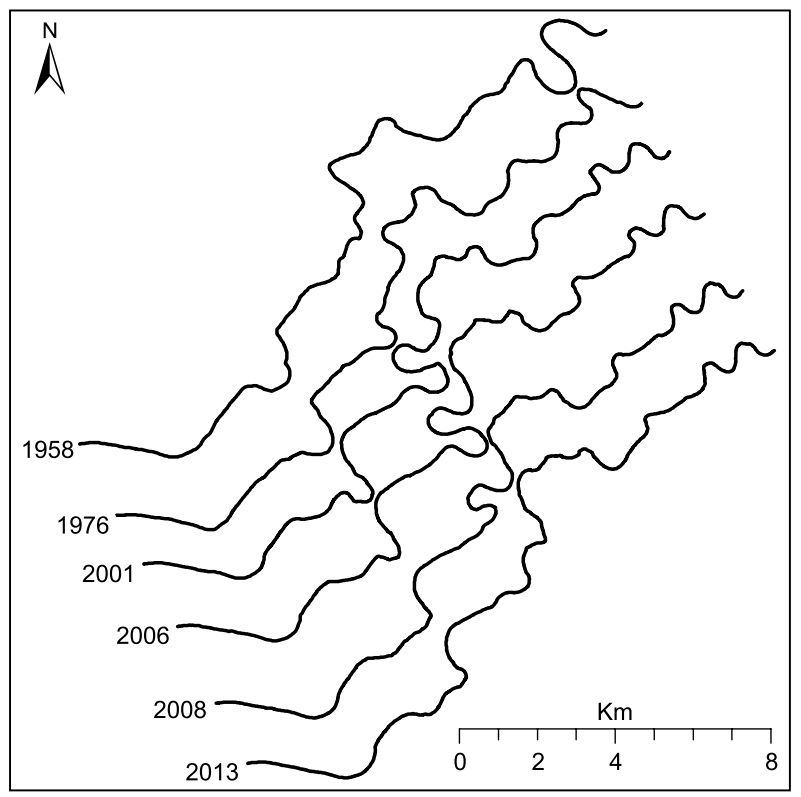

Fig. 4. Successive channel planform changes from 1958 to 2013 along the reaches of Bosna River.

Table 4. Lateral shift of the centreline of Bosna River - total in meter (m).

\begin{tabular}{|c|c|c|c|c|c|}
\hline Shift in regard to 1958 year & 1976 & 2001 & 2006 & 2008 & 2013 \\
\hline Max shift $[\mathrm{m}]$ & 517.8 & 934.7 & 1055.3 & 467.0 & 506.2 \\
\hline Average shift [m] & 106.2 & 178.8 & 185.0 & 140.1 & 132.4 \\
\hline Standard deviation $[\mathrm{m}]$ & 102.8 & 182.1 & 197.4 & 113.7 & 112.5 \\
\hline Coefficient of variation [\%] & 96.8 & 101.8 & 106.7 & 81.2 & 85.0 \\
\hline Shift in regard to 1976 year & & 2001. & 2006. & 2008. & 2013. \\
\hline Max shift $[\mathrm{m}]$ & & 654.0 & 765.4 & 600.5 & 635.5 \\
\hline Average shift [m] & & 145.4 & 150.1 & 121.8 & 120.2 \\
\hline Standard deviation [m] & & 143.4 & 156.5 & 111.8 & 110.4 \\
\hline Coefficient of variation [\%] & & 98.6 & 104.3 & 91.7 & 91.8 \\
\hline Shift in regard to 2001 year & & & 2006. & 2008. & 2013. \\
\hline Max shift $[\mathrm{m}]$ & & & 282.0 & 266.2 & 275.9 \\
\hline Average shift [m] & & & 39.9 & 42.9 & 60.7 \\
\hline Standard deviation $[\mathrm{m}]$ & & & 46.2 & 50.2 & 59.4 \\
\hline Coefficient of variation [\%] & & & 115.7 & 117.2 & 98.0 \\
\hline Shift in regard to 2006 year & & & & 2008. & 2013. \\
\hline Max shift $[\mathrm{m}]$ & & & & 252.0 & 247.5 \\
\hline Average shift [m] & & & & 22.8 & 42.2 \\
\hline Standard deviation [m] & & & & 31.8 & 46.0 \\
\hline Coefficient of variation [\%] & & & & 139.7 & 109.1 \\
\hline Shift in regard to 2008 year & & & & & 2013. \\
\hline Max shift $[\mathrm{m}]$ & & & & & 204.4 \\
\hline Average shift [m] & & & & & 37.9 \\
\hline Standard deviation [m] & & & & & 43.6 \\
\hline Coefficient of variation [\%] & & & & & 115.0 \\
\hline
\end{tabular}


934.7 m, 1958-2006, 1055.3 m, 1958-2008, 467.0 m are also significant and the period from 1958 to 2013, $506.2 \mathrm{~m}$ (Table 4).

\section{Discussion}

Events such as flooding can trigger dramatic and sudden changes in rivers and streams. The Bosna River is a good example, which represents the existence of all natural conditions for frequent and large scale floods. As direct consequence of the climatic-hydrological characteristics of the Bosna River basin (which are manifested in discharge regime changes), once a year the Bosna River overflows, and the area of lower course of the Bosna River basin is endangered by floods. Changes in water and sediment discharge are the major factors that contribute to hydraulic changes in Bosna River geometry. The riverbed of Bosnia River is formed in its own alluvium and it shifts often. There are accumulation formations in the riverbed, such as islands, while adversely mechanical characteristics of banks combined with varying shifts of high and low water on both Bosna and Sava River (the Sava River retardation and coincidence of high and low water) are causing bank erosion, material loss, that is, erosion processes and accretion. All works on the riverbed regulation so far have been local and dealing with urban settlement protection on this section of Bosna River. Intensive urbanisation and various construction work needs natural material such as sand and boulder. Exploitation of these materials have been done in chaotic manner, with absence of planning, partly from riverbed and partly from inundation area which influence bank stability and causes processes of erosion and accretion to occur. In the absence of appropriate measures and riverbed regulation, most human activities will lead to accelerated rates of erosion and accretion.

Regarding to natural conditions, the Kolubara River basin (Serbia) is similar to the Bosna River basin. Unlike the other rivers with similar hydrological characteristics, the river network in the lower course of the Kolubara River basin were changed rapidly during the $\mathrm{XX}$ century because of direct human impact. The rate of the Kolubara river channel shifting along the lower course of the Kolubara River basin is $47 \mathrm{~m}$ in average for the period of 37 years, which means $1.27 \mathrm{~m}$ per year. The most intensive rate of the channel shifting was $224 \mathrm{~m}$ in 37 years, with the average of $6.05 \mathrm{~m}$ per a year (Dragicevic et al. 2012).

Channel shifting of the Bosna River has caused serious problems, such as disappearance of arable land, forests, pastures and meadows, economic loss due to the reduction of agricultural production. Bank erosion, accretion and channel shifting, soil loss, sediment load deposition, floods, soil and water pollution are representing major environmental problems in the Bosna River basin.

Beside its geomorphological significance, the results of this investigation are applicable in the field of geopolitical questions, as well as in different aspects of the environmental protection. Bank erosion and the channel shifting could become a geopolitical and security question if the border between states or other political-territorial entities is drawn along the river. In the lower course of the Bosna River, the bank erosion caused many problems with the demarcation between two entities. In this area, the farmers who had arable land parcels on the right bank (50 years ago), lost parts of the parcels or whole parcels due to intensive channel shifting. In recent time, their land parcels have been located on the left bank. Therefore, any change in the lower course means not only moving the border between the Republic of Srpska and the Federation of Bosnia and Herzegovina, but also cause for misunderstandings that can evolve into a new large scale conflict.

\section{Conclusion}

The analysis showed that the average movement in the period 1958-2013 amounted to $90.4 \mathrm{~m}$ to the left, and the maximum value of this movement in the analysed period was $330.7 \mathrm{~m}$. In terms of channel shifting to the East, it was found that its average value in the period 1958-2013 amounted to $156.1 \mathrm{~m}$, and that in this period the value of the maximum movement in this direction was 506.2 $\mathrm{m}$. The Bosna riverbed average movement in the period 1958-2013 was established in the amount of $132.4 \mathrm{~m}$. During this period, the average lateral channel migration was $2.5 \mathrm{~m}$ per year. 
Apart from the above analyses that are of the local (relating to the municipalities located on the watercourse banks) character, the bank erosion may result in serious consequences (conflict) that come out of the national framework. For further research, it is necessary to link fluvial processes with socio-economic factors in the order to predict the future development of the fluvial landscape. In addition to landscape degradation, lateral migration of the Bosna River has caused serious problems for the disappearance of arable land, but also economic loss due to the reduction of agricultural production and the administrative border changes.

\section{Acknowledgments}

The work described in this paper was done within the project financed by Ministry of Science and Technology of Republic of Srpska.

\section{References}

Blanka V., Kiss T., 2011. Effect of different water stages on bank erosion, case study of river Hernad, Hungary. Carpathian Journal of Earth and Environmental Sciences 6(2): 101-108.

Downward S.R., Gurnell A.M., Brookes A., 1994. A methodology for quantifying river channel planform change using GIS. International Association of Hydrological Sciences 224: 449-456. DOI: 10.4236/jgis.2014.62010

Downward S.R., 1995. Information from topographic survey. In: Gurnell A.M., Petts G.E. (eds), Changing river channels. Wiley, New York: 303-323.

Dragicevic S., Zivkovic N., Roksandic M., Kostadinov S., Novkovic I., Tosic R., Stepic M., Dragicevic M., Blagojevic B., 2012. Land Use Changes and Environmental Problems Caused by Bank Erosion: A Case Study of the Kolubara River Basin in Serbia. In: Appiah-Opoku S. (ed), Environmental Land Use Planning. InTech, Rijeka: 3-20. DOI: $10.5772 / 50580$

Dragicevic S., Tosic R., Stepic M., Zivkovic N., Novkovic I., 2013. Consequences of the River Bank Erosion in the Southern Part of the Pannonian Basin: Case Study - Serbia and the Republic of Srpska. Forum geografic 12(1): 5-15. DOI: 10.5775/fg.2067-4635.2013.008.i

Duan J.G., 2005. Analytical approach to calculate rate of bank erosion. Journal of Hydraulic Engineering 131(11): 980-990. DOI: 10.1061/(ASCE)0733-9429(2005)131: 11(980)

Floriou I., 2011. Types of riverbed along the lower course of the Buzau River. Forum geographic 10(1): 91-98. DOI: 10.5775/fg.2067-4635.2011.022.i

Grove J.F., Croke J.C., Thompson C.J., 2013. Quantifying different riverbank erosion processes during an extreme flood event. Earth Surface Processes and Landforms 38(12): 1393-1406. DOI: 10.1002/esp.3386

Gurnell A.M., Downward S.R., Jones R., 1994. Channel planform change on the River Dee meanders, 1876-1992. Reg- ulated Rivers: Research \& Management 9(4): 187-204. DOI: 10.1002/rrr.3450090402

Gurnell A.M., 1997. Channel change on the River Dee meanders, 1946-1992, from the analysis of air photographs. Regulated Rivers: Research and Management 13(1), 13-26. DOI: 10.1002/(SICI)1099-1646(199701)13:1<13::AID-RRR420>3.0.CO;2-W

Henshaw A.J., Thorne C.R., Clifford N.J., 2013. Identifying causes and controls of river bank erosion in a British upland catchment. Catena 100: 107-119. DOI: 10.1016/j. catena.2012.07.015

Hooke J.M., 1979. An analysis of the processes of river bank erosion. Journal of Hydrology 42: 39-62. DOI: 10.1016/00221694(79)90005-2

Hooke J.M., 1980. Magnitude and distribution of rates of river bank erosion. Earth Surface Processes and Landforms 5: 143-157. DOI: 10.1002/esp.3760050205

Hooke J.M., Redmond C.E., 1989. Use of cartographic sources for analysing river channel change with examples from Britain. In: Petts G.E., Möller H., Roux A.L. (eds), Historical Change of Large Alluvial Rivers: Western Europe. Wiley, Chichester: 79-93.

Hooke J., 2003. River meander behaviour and instability: a framework for analysis. Transactions of the Institute of British Geographers 28(2): 238-253. DOI: 10.1111/14755661.00089

Hooke J.M., 2007. Spatial variability, mechanism and propagation of change in an active meandering river. Geomorphology 84(3-4): 277-296. DOI: 10.1016/j.geomorph.2006.06.005

Hudson P.F., Kesel R.H., 2000. Channel migration and meander-bend curvature in the lower Mississippi River prior to major human modification. Geology 28(6): 531534. DOI: 10.1130/0091-7613(2000)28<531: CMAMCI> 2.0.CO;2

Hughes M.L., McDowell P.F., Marcus W.A., 2006. Accuracy assessment of georectified aerial photographs: implications for measuring lateral channel movement in a GIS. Geomorphology 74(1-4): 1-16. DOI: 10.1016/j.geomorph.2005.07.001

Kiss T., Fiala K., Sipos G., 2008. Alterations of channel parameters in response to river regulation works since 1840 on the Lower Tisza River (Hungary). Geomorphology 98: 96-110. DOI: 10.1016/j.geomorph.2007.02.027

Lawler D.M., 1993. The measurement of riverbank erosion and lateral channel change: A review. Earth Surface Processes and Landforms 18(9): 777-821. DOI: 10.1002/ esp.3290180905

Lawler D.M., Grove J.R., Couperwaite J.S., Leeks G.J.L., 1999. Downstream change in river bank erosion rates in the Swale-Ouse system, northern England. Hydrological Processes 13(7): 977-992. DOI: 10.1002/(SICI)10991085(199905)13:7<977::AID-HYP785>3.0.CO;2-5

Mount N., Louis J., 2005. Estimation and propagation of error in measurements of river channel movement from aerial imagery. Earth Surface Processes and Landforms 30: 635-643. DOI: 10.1002/esp.1172

Nicoll T.J., Hickin E.J., 2010. Planform geometry and channel migration of confined meandering rivers on the Canadian prairies. Geomorphology 116(1-2): 37-47. DOI: 10.1016/j.geomorph.2009.10.005

Petts G.E., 1989. Historical analysis of fluvial hydrosystems. In: Petts G.E., Möller H., Roux A.L. (eds), Historical change in large Alluvial Rivers. Wiley, New York: 1-18. 
Radoane M., Pandi G., Radoane N., 2010. Contemporary bed elevation changes from the eastern Carpathians, Carpathian Journal of Earth and Environnemental Sciences 5(2): 49-60.

Richard G.A., Julien P.Y., Baird D.C., 2005. Statistical analysis of lateral migration of the Rio Grande, New Mexico. Geomorphology 71 (1-2): 139-155. DOI: 10.1016/j.geomorph.2004.07.013

Roksandic M., Dragicevic S., Zivkovic N., Kostadinov S., Zlatic M., Martinovic M., 2011. Bank erosion as a factor of soil loss and land use changes in the Kolubara river basin, Serbia. African Journal of Agricultural Research 6 (32): 6604-6608.

Thorne C.R., 1982. Processes and mechanisms of river bank erosion. In: Hey R.D., Bathurst J.C., Thorne C.R. (eds), Gravel Bed Rivers. Wiley, Chichester: 227-271.

Tiegs S.D., Pohl M., 2005. Planform channel dynamics of the lower Colorado River: 1976-2000. Geomorphology 69 (14): 14-27. DOI: 10.1016/j.geomorph.2004.12.002

Tosic R., Lovric N., Dragicevic S., 2014. Land use changes caused by bank erosion along the lower part of the Bosna River from 2001 to 2013, Bulletin of the Serbian Geographical Society 94(4): 49-58. DOI: 10.2298/GSGD1404049T
Wellmeyer J., Slattery M., Phillips J., 2005. Quantifying downstream impacts of impoundment on flow regime and channel planform, lower Trinity River, Texas. Geomorphology 69(1-4): 1-13. DOI: 10.1016/j.geomorph.2004.09.034

Weng Q., 2002. Land use change analysis in the Zhujiang Delta of China using satellite remote sensing, GIS and stochastic modeling. The Journal of Environmental Management 64 (3): 273-284.

Winterbottom S.J., Gilvear D.J., 2000. A GIS-based approach to mapping probabilities of river bank erosion: regulated River Tummel, Scotland. Regulated Rivers: Research $\mathcal{E}$ Management 16(2): 127-140. DOI: 10.1002/(SICI)10991646(200003/04)16:2<127::AID-RRR573>3.0.CO;2-Q

Yao Z., Ta W., Jia X., Xiao J., 2011. Bank erosion and accretion along the Ningxia-Inner Mongolia reaches of the Yellow River from 1958 to 2008. Geomorphology 127: 99-106. DOI: 10.1016/j.geomorph.2010.12.010

Zaharia L., Grecu F., Ioana-Toroimac G., Neculau G., 2011. Sediment transport and river channel dynamics in Romania - variability and control factors. In: Manning A.J. (ed.), Sediment Transport in Aquatic Environments. InTech, Rijeka: 293-316. DOI: 10.5772/21416 